\title{
Epidemiology and the consequences of fear of missing out (FOMO). The role of general practitioners in early diagnosis, treatment and prevention of FOMO in teenagers and young adults Epidemiologia i skutki zdrowotne syndromu FOMO. Rola lekarzy rodzinnych we wczesnym rozpoznawaniu, leczeniu i profilaktyce syndromu FOMO u nastolatków i młodych dorosłych
}

\author{
'General Practice Clinic, University Children's Clinical Hospital in Bialystok, Białystok, Poland \\ ${ }^{2}$ School Complex No. 1 named after Marshal of Józef Klemens Pitsudski, Bielsk Podlaski, Poland \\ Correspondence: Anna Citko, MD, PhD, Wiosenna 2B, Fasty, 15-694 Białystok, Poland, e-mail: anka234@gmail.com
}

\begin{abstract}
Published reports, mainly concerning education and psychology, imply that FOMO may be a consequence of excessive and incorrect use of the Internet, social media and mobile devices. FOMO may be explained as a fear of missing out on important information. It disappears when people with FOMO check notifications on their telephone or sit down at a computer, and this leads to the development of a vicious circle. FOMO may lead to the development of e-addictions. A survey study conducted in a group of 1,060 randomly selected Poles aged 15 and older showed that one in five Internet users from the younger group of subjects had a high FOMO index. One fifth of respondents with FOMO suffer from somatic symptoms: nausea, dizziness, abdominal pain or increased sweating, when not using social media. The results of these studies prove that the FOMO problem is clearly noticeable among digital media users. Further studies on the incidence of FOMO are needed, particularly in the case of teenagers and young adults, to evaluate the health consequences of FOMO. Prevention of FOMO and the associated e-addictions should be implemented not only at schools, for example, as a part of the school syllabus, but also in the form of therapeutic treatments offered to people using digital tools in a risky way. General practitioners can be an important link in the chain of FOMO prevention, diagnosis, and treatment. The advantageous solutions may include, for example, the implementation of a pilot programme for the prevention of FOMO and e-addictions addressed to teenagers, that will be financed from the National Health Fund resources and included in general practitioners' practices.
\end{abstract}

Keywords: FOMO, addiction, prevention, teenagers

Streszczenie W piśmiennictwie, głównie z zakresu pedagogiki i psychologii, podkreśla się, że skutkiem nadmiernego i niewłaściwego korzystania z internetu, mediów społecznościowych oraz urządzeń mobilnych może być syndrom FOMO (fear of missing out). W wolnym tłumaczeniu syndrom FOMO to obawa przed utratą ważnej informacji, która znika, gdy osoba z syndromem FOMO sprawdzi powiadomienia na telefonie lub zasiądzie przed komputerem, co prowadzi do powstania „błędnego koła”. Syndrom FOMO może być przyczyną rozwoju e-uzależnień. Na podstawie wyników badań ankietowych przeprowadzonych w grupie 1060 losowo wybranych Polaków w wieku od 15 lat wzwyż stwierdzono, że co piąty internauta z najmłodszej grupy badanych należy do osób $\mathrm{z}$ wysokim indeksem FOMO. U 1/5 respondentów dotkniętych syndromem FOMO w przypadku niekorzystania z mediów społecznościowych występują objawy somatyczne: nudności, zawroty głowy, bóle brzucha czy zwiększona potliwość. Wyniki tych badań dowodzą, że problem ten jest wyraźnie zauważalny wśród użytkowników mediów cyfrowych. Konieczne jest prowadzenie dalszych badań dotyczących częstości występowania syndromu FOMO, szczególnie w grupie nastolatków i młodych dorosłych, mających na celu także ocenę skutków zdrowotnych tego zaburzenia. Profilaktyka syndromu FOMO i związanych z nim e-uzależnień powinna znaleźć swoje miejsce nie tylko w obrębie działań szkoły, na przykład w ramach obowiązujących statutów szkolnych, ale także w zakresie pomocy leczniczej udzielanej osobom ryzykownie korzystającym z narzędzi świata cyfrowego. Lekarze rodzinni mogą być ważnym ogniwem w profilaktyce, rozpoznawaniu i leczeniu syndromu FOMO. Do korzystnych rozwiązań może należeć na przykład wprowadzenie w praktykach medycyny rodzinnej finansowanego ze środków Narodowego Funduszu Zdrowia pilotażowego programu profilaktyki syndromu FOMO i e-uzależnień w grupie nastolatków. 


\section{INTRODUCTION}

$\mathrm{T}$ he Internet has virtually eliminated other traditional media such as television, radio and the press in recent years. It is estimated that of the 7.5 billion people living in the world, almost 3.6 billion are active Internet users. The Internet has become a part of modern life, accompanying people everyday from morning till evening, or even longer in some cases. Therefore, the Internet is sometimes referred to as a "hypermedium" in literature. This term is used to emphasise the fact that the global network takes over the roles of traditional media. As a result, young people are currently referred to as "digital natives." A native is a permanent, indigenous inhabitant of a given region. Young people are natives living in the digital world. Cyberspace is their natural environment to which they do not need to adapt, but which they perceive as "native"(1).

Social portals are still enjoying popularity in Poland ${ }^{(2)}$. They eliminate geographical, cultural, and linguistic barriers (the latter ones as a result of the translation function, which is increasingly common in social media). With only little effort and in a short time, they make it easier to maintain acquaintances, renew old ones and make new ones ${ }^{(1)}$. In addition, social networks allow for posting photographs and multimedia files, exchanging information and opinions, as well as sharing thoughts with friends ${ }^{(2)}$. This way, interpersonal communication takes place not only face to face and is no longer limited by space ${ }^{(3)}$. As a result, social networking connects people, provides entertainment, and allows for contacting people without leaving home ${ }^{(4)}$. Facebook is the most popular social network in Poland, with almost 14 million people using this service on a daily basis ${ }^{(3)}$. The 2011/2012 EU NET ADB project (Research on Internet abuse among young people in Poland and Europe) showed that social networking sites are the space of online activity most commonly practised by European adolescents aged 14-17 years. The study was conducted in a representative sample of 13,300 young people from 7 European countries (Spain, the Netherlands, Iceland, Poland, Greece, Germany, Romania), including 2,045 Poles. The research was carried out with a diagnostic survey method using, among other things, the following questionnaires: a questionnaire on Internet use (sociodemographic data, family information, school achievements, characteristics of Internet use, parental control), Internet/online gaming/gambling addiction test, and a self-assessment questionnaire. It was found that $32 \%$ of Polish adolescents (39.4\% of the European sample) spend at least 2 hours daily on social networks during schooldays. A total of $90 \%$ of Polish respondents (92\% of the Polish sample) have at least one account on a social networking site ${ }^{(5)}$. Klimczak et al. conducted their study in a group of 524 middle school, high school and university students in Olsztyn. Nearly half of respondents (46.75\%) reported using instant messengers when connected to the network. Social networking sites were used by $36.45 \%$ of women and $26.71 \%$ of men $^{(2)}$. A study conducted by
Warzecha in a group of 470 high-school, 248 middleschool and 319 university students aged 13-29 years from Silesia Province showed that about $87 \%$ of middle-school students and about $89 \%$ of high-school and university students have accounts on social networking sites. Most respondents have a profile on at least one social networking site and spend 30 minutes to 1 hour using $\mathrm{it}^{(4)}$.

The results of studies on the scale of social media and mobile phone addiction are alarming, especially among adolescents and young adults ${ }^{(6,7)}$. According to the EU NET ADB research project, $13.3 \%$ of Polish respondents use the Internet in a dysfunctional way (i.e. abuse the Internet or are at risk of Internet abuse) $)^{(5)}$. In 2015, ESPAD (European School Survey Project on Alcohol and Other Drugs) was conducted to assess, among other things, the use of social media among Polish 16-year-olds. A total of 3,289 adolescents were included in the study. The study showed that one in four 16-year-olds use social networking for at least 3 hours a day. The study also showed that 4 out of 5 Polish adolescents spend at least one hour daily using social media. About $33.2 \%$ of Polish adolescents expressed their concerns about spending too much time online. Also, $34.3 \%$ of 16-year-olds reported their parents' concerns in this regard ${ }^{(6)}$. A survey was conducted in Częstochowa in 2011. A total of 100 respondents participated in the survey. All respondents had mobile phones, with 92 respondents owning a mobile phone for more than 2 years. Nearly $92 \%$ of respondents presented with the symptoms of smartphone addiction (SPA), such as attaching excessive importance to owning a mobile phone, keeping it within range of vision at all times, experiencing discomfort manifested in a poor mood, anxiety or panic when the battery is discharged, and justifying one's own behaviour with safety and convenience ${ }^{(7)}$. A total of 805 Polish adolescents aged 11-16 years participated in an international EU Kids Online project, which was conducted in 25 countries. It was shown that $9 \%$ of respondents presented with all listed symptoms of dependence such as lack of appetite, insomnia, unsuccessful attempts to control the time spent on the Internet, a feeling of lack if unable to use the Internet, no time for family and friends, neglecting duties, aimless surfing the Internet ${ }^{(8)}$.

Published reports, mainly concerning education and psychology, emphasise that FOMO may be a consequence of excessive and incorrect use of the Internet, social media and mobile devices. FOMO may be explained as a fear of missing out on important information, which disappears when a person with FOMO checks notifications on their telephone or sits down at a computer, and this leads to a vicious circle ${ }^{(9)}$. According to some authors, FOMO may be also associated with an urge to watch some television programmes ${ }^{(10)}$. According to literature, the concept of fear of missing out was first used by Dan Herman in the mid-1990s to describe a fear of a failure to exhaust all available opportunities and missing the expected joy associated with succeeding in doing so. In 2004, Patrick McGinnis defined FOMO as "overoptimisation" in one of his interviews. 
Dan Herman and Patrick McGinnis did not correlate FOMO only with the use of social media. This was done by global mass media, such as "The New York Times," "The Times," and "The Guardian." According to these sources, social media increased FOMO, affecting the self-esteem and the well-being of users ${ }^{(11)}$.

It is also worth emphasising that a term "discomgoogolation," which is used to describe anxiety felt by someone who is unable to access the Internet, is increasingly common in the subject literature ${ }^{(2)}$.

The fear of losing important information is generated to a large extent by application designers. For example, Google Play offered about 3.6 million tools to facilitate daily media use at the end of 2017. Similar to a Las Vegas casino machine, which may reward us with money with every pull of the lever, each time we pull our phone from our pocket, we expect a new reward in the form of a new notification. When browsing Facebook, we expect a reward in the form of new information about our friends' activity. We browse Instagram to be "rewarded" with new photographs of people we follow on Instagram. Another win leads to more "games," i.e. new opportunities to win a prize ${ }^{(12)}$. Due to the fear of missing something and waiting for another win, social media is used immediately after getting out of bed or before going to bed as well as during meals ${ }^{(13)}$. The inability to log into the social networking site causes anxiety or discomfort ${ }^{(14)}$. Studies have shown that individuals with FOMO have a tendency to use social platforms in surprising places and circumstances, such as school, theatre or church ${ }^{(11)}$.

Individuals with FOMO not only constantly check whether something happened that could escape their attention, but they also feel the urge to share the smallest details of their lives, such as photographs of food served in a new, fashionable restaurant or reports on where they are, what they are wearing, or how they are feeling, in social media. They are electronic exhibitionists, who post information about themselves guided by the need to show off, expecting to receive positive comments in return ${ }^{(9)}$.

Low self-esteem, poor motivation, fear of rejection and the need for acceptance contribute to increased Internet use $\mathrm{e}^{(9,15)}$. Buglass et al. included 506 participants, with women accounting for $53 \%$, in their study. It was concluded that the abuse of Facebook and the associated FOMO were significantly more common in individuals with reduced self-esteem ${ }^{(15)}$. This may result from the fact that people with low self-esteem feel more confident online, which helps them overcome difficulties in establishing interpersonal contacts ${ }^{(9)}$.

The problem of FOMO appears primarily in scientific psychology, education and marketing reports ${ }^{(11)}$. Psychiatry and general practice reports in this field, publications on FOMO prevention in relation to general practitioners (GPs) in particular, are missing. It is worth mentioning that the screening among children and adolescents is performed by GPs, who establish a long-lasting relationship with the patient, which may aid prevention and detection

\section{THE SCALE OF FOMO IN POLAND AND GLOBALLY}

A nationwide survey was conducted among people aged $\geq 15$ years in Poland from 18 to 28 March 2018. A total of 1,060 people participated in the survey. One of the thematic sections of the questionnaire included 10 questions representing the so-called FOMO scale rated 0-100, which was developed and verified by Andrew Przybylski et al. The questionnaire was the basis for developing FOMO index. The study showed that $16 \%$ of Polish Internet users belong to the group with a high FOMO index. Interestingly, one in five Internet users in the youngest age group had a high FOMO index. Therefore, these studies clearly indicate that FOMO affects not only a small group of Internet users, but the phenomenon is clearly noticeable among all digital media users ${ }^{(11)}$.

For comparison, a study in a group of 2,084 adult Americans demonstrated that $56 \%$ of social media users (e.g. Facebook) were affected by $\mathrm{FOMO}^{(13)}$. A study conducted among 150 inhabitants of India showed that $37 \%$ of Internet users experienced $\mathrm{FOMO}^{(16)}$. In a group of 717 students from Bosnia and Herzegovina, FOMO affected 20\% of respondents (mean age 13 years) ${ }^{(17)}$.

A study including 1,521 Australians $\geq 18$ years of age and 210 Australians 13-17 years of age was conducted in August 2015. High FOMO index was reported for $48 \%$ of boys and $38 \%$ of girls $13-15$ years of age, and $50 \%$ of boys and $66 \%$ of girls $16-17$ years of age. Almost half of respondents aged $18-25$ years $(48 \%)$ were affected by $\mathrm{FOMO}^{(18)}$.

\section{HEALTH CONSEQUENCES OF FOMO}

It may be concluded based on the conducted studies that people with FOMO present with anxiety disorders, depression and risky health behaviours ${ }^{(19-21)}$. Barry et al. conducted their study in 226 14-17-year-olds from the United States. It was concluded based on the study that depression and anxiety were significantly more common in individuals with $\mathrm{FOMO}^{(19)}$.

Furthermore, the fear of not taking advantage of an opportunity causes distraction during learning (using Facebook during lectures) and driving (making phone calls, writing and reading short messages or e-mails). For example, according to data from the United States Road Safety Authority, $12 \%$ of all fatal car accidents are due to inattention caused by using smartphones ${ }^{(13)}$.

Riordan et al. investigated 432 students in New Zealand aged 18-25 years. FOMO was correlated with alcohol abuse $\mathrm{e}^{(21)}$.

FOMO may contribute to e-addictions, such as social networking or smartphone addiction ${ }^{(9,11)}$. For example, Poprawa showed a significant relationship between increased problematic use of the Internet and activities related to searching for contacts, using chat rooms and discussion forums in the population of children, adolescents and young adults ${ }^{(22)}$. Wolniewicz et al. included 296 residents of 
the United States in their study. Respondents who abused smartphones were included in the group with high FOMO index ${ }^{(23)}$. Similar conclusions were drawn by Eide et al., who conducted their study in a group of 127 respondents aged 18-48 years ${ }^{(24)}$. Oberst et al. conducted their study in 5,280 Latin Americans. Individuals with high FOMO index included those abusing smartphones and social networking sites $^{(25)}$. The EU NET ADB research showed a strong correlation between using social networking sites and problematic Internet use. It should be added that this relationship is stronger for using social networks than online gaming ${ }^{(5)}$. Both smartphone and social media addiction are behavioural addictions. Behavioural addiction is a compulsive need to engage in a certain activity not related to the use of psychoactive substances. According to the International Statistical Classification of Diseases and Related Health Problems, $10^{\text {th }}$ revision (ICD-10), this entity was classified as F63.9, i.e. habit and impulse disorder, unspecified ${ }^{(1)}$. Franchina et al. included 2,663 adolescents from the Flemish Region in Belgium in their study. The occurrence of FOMO was associated with problematic use of the Internet and smartphones ${ }^{(26)}$. Alt et al., who conducted their study in a group of 296 students, observed a relationship between FOMO and excess use of social media ${ }^{(27)}$.

Behavioural addictions in young people can significantly disturb the process of normal personal development ${ }^{(1)}$.

Jenaro et al. conducted a study in a group of 337 students (mean age $21.6 \pm 2.45$ years) in Spain. Internet abuse was closely correlated with insomnia and depression ${ }^{(28)}$. Sahin et al. conducted their study in 576 Turkish students (mean age $20.83 \pm 1.9$ years). The sleep quality worsened with increasing mobile phone addiction level ${ }^{(29)}$. Dhira et al. showed that excess use of social media was associated with anxiety disorders and depression ${ }^{(30)}$. Similar conclusions were drawn by Pantic et al., who conducted their study in a group of 160 university students in Serbia ${ }^{(31)}$. Analyses showed that psychosocial problems, such as anxiety disorders, depression, withdrawal, thought and attention disorders, inappropriate and aggressive behaviours, were significantly more common among individuals who intensely used social networking sites (at least 2 hours daily). The strongest correlation was observed for inappropriate and aggressive behaviours ${ }^{(32)}$. Demirci et al. investigated a group of 319 Turkish students. Anxiety disorders and depression were significantly more common in individuals with smartphone addiction compared to other respondents ${ }^{(33)}$.

Leena et al. conducted their study in 3,485 adolescents from Finland. Risky health behaviours were closely correlated with mobile phone addiction ${ }^{(34)}$. A study in Taiwan also revealed a relationship between smartphone use and psychoactive substance dependence (e.g. drug dependence) as well as behavioural addictions, such as credit card abuse ${ }^{(13)}$. At the same time, it should be remembered that the use of mobile phones involves emission of electromagnetic field. Some studies indicate that both cancer and cardiovascular, nervous and reproductive disorders are more common in people exposed to the electromagnetic field compared to the general population ${ }^{(35)}$. Furthermore, it was found that mobile phone users are at a significantly increased risk of acoustic neuroma and an increased risk of ipsilateral glioma ${ }^{(36,37)}$.

It is worth mentioning that $1 / 5$ of Polish Internet users with high FOMO index experienced somatic symptoms such as nausea, dizziness, abdominal pain (23\%) or increased sweating $(21 \%)$ when not using social media ${ }^{(11)}$. Such symptoms are typical of withdrawal syndrome ${ }^{(9)}$. The symptoms of Internet withdrawal syndrome may include anxiety, depression, suicide attempts, psychosomatic discomfort, headaches and dizziness, musculoskeletal pain, visual disturbances, insomnia, nausea, loss of appetite, hyperactivity, and photosensitive epilepsy.

Prolonged use of the Internet may enhance the symptoms of mental disorders, such as psychoses, anxiety disorders, phobias, manic-depressive disorders, affective disorders, and personality disorders. In extreme cases, Internet addiction can take the form of obsessive-compulsive disorder ${ }^{(2)}$. The above-described and other negative effects of FOMO syndrome and the related behavioural addictions are summarised in Tab. 1.

\section{THE ROLE OF DOCTORS, GENERAL PRACTITIONERS IN PARTICULAR, IN THE PREVENTION, DIAGNOSIS AND TREATMENT OF FOMO}

As already mentioned, FOMO leads to both Internet and smartphone addictions. They have serious health consequences, which indicates the importance of prevention of FOMO and the related behavioural addictions. It is safe to say that Internet and smartphone addiction, like alcohol or drug dependence, are a real and serious threat to a young person $^{(2,38)}$. The negative physical, psychological and social effects of the FOMO syndrome and the related behavioural addictions indicate the importance of taking appropriate preventive measures.

Further research is needed to estimate the scale of FOMO, especially among adolescents and young adults. The issue of e-addictions should be incorporated not only into school prevention of addictions, e.g. as part of school syllabus, but also in the field of therapy for those already addicted or involved in the risky use of digital media. General practitioners should play an important role in the prevention, early detection and treatment of behavioural addictions. This results from the fact that the primary healthcare system brings healthcare as close as possible to where people live and work. For this reason, it deals with health problems in physical, psychological, social, cultural and existential dimensions. Furthermore, in addition to parents and teachers, it is GPs who have the opportunity to shape healthy behaviours in adolescents ${ }^{(39)}$. The issue of participation and potential effectiveness of GPs in the treatment of behavioural addictions requires further research. 


\begin{tabular}{|l|l|l|}
\hline Physical & Social & Psychological \\
\hline Headaches and dizziness & Inability to spend free time creatively & Poor sense of security \\
\hline Impaired vision & $\begin{array}{l}\text { Poor school performance (distraction, inability to focus on one } \\
\text { activity, lack of concentration, insufficient time devoted to } \\
\text { learning, procrastination) }\end{array}$ & Anxiety \\
\hline Dry eye syndrome & Problems with interpersonal relations & Emotional dysregulation \\
\hline Increased sweating & $\begin{array}{l}\text { Isolation } \\
\text { Loneliness }\end{array}$ & Identity disorders \\
\hline Loss of appetite & Limited interests & $\begin{array}{l}\text { Loss of self-control } \\
\text { Aggressive behaviours } \\
\text { Inappropriate behaviours }\end{array}$ \\
\hline Nausea & Poor communication skills & Thought disorders \\
\hline Abdominal pain & & Impaired attention \\
\hline Eating disorders & & Addiction to psychoactive substances \\
\hline Photosensitive epilepsy & & Other behavioural addictions, such as credit card abuse \\
\hline Reproductive disorders & & Insomnia \\
\hline Cancer, e.g. acoustic neuroma, ipsilateral glioma & & \\
\hline
\end{tabular}

Tab. 1. Negative consequences of FOMO

Annual check-up, especially in 13- and 16-year-olds, as well as high-school graduates is an important opportunity for GPs to detect behavioural addictions in their young patients. During such a check-up, the doctor should inform parents on the need for parental monitoring to limit the screen time, including computer screen time, to 2 hours daily as well as provide guidance on the proper use of a mobile phone by a young person ${ }^{(32)}$. A GP may use a 10-item questionnaire developed by Andrew Przybylski for FOMO diagnosis ${ }^{(13)}$. Completing a Facebook addiction questionnaire by an adolescent could also be an interesting solution. It contains only 6 questions and is easy to interpret ${ }^{(40)}$. This type of diagnostic tool could be also easily used by a school nurse. In the case of suspected e-addiction, a short-term preventive intervention could be implemented by a GP. However, it should be remembered that such patients not only need effective measures, but also kindness as medical management should be based on kind and helpful attitude of the doctor, who is ready to offer selfless help ${ }^{(41)}$. For this reason, a short preventive intervention should take the form of a motivational conversation to encourage the patient to change their risky behaviour through kindness and empathy rather than by confrontation $^{(42)}$. Parents should be also informed on the possible emotional causes of problematic Internet use by their child and, in justified cases, advised to seek psychological or psychiatric consultation.

The therapy of FOMO and the associated behavioural addictions involves:

- becoming aware of the harmful effects of problematic Internet use;

- self-control;

- consistent discontinuation of using the Internet as the only form of spending free time ${ }^{(13)}$.

FOMO should be considered in the case of unexplained medical symptoms in adolescents (i.e. when diagnostic ziness, abdominal pain, eating disorders, musculoskeletal pain, dry eye syndrome or emotional dysregulation. It is worth paying attention to potential behavioural addictions in adolescents with nicotine dependence, those presenting with sleeping disorders or psychosocial problems, including inappropriate and aggressive behaviours ${ }^{(32)}$.

Educational advice financed by the National Health Fund could also represent a solution of the problem. This would motivate doctors to offer this type of advice.

Properly qualified nurses can offer invaluable help in health education provided by a doctor. Since the distance between a patient and a nurse is usually smaller, it allows to fell less intimidated when talking to a nurse compared to doctors $^{(43)}$. Implementation of educational advice offered by nurses in general medicine practices could be a solution. Organisational aspects, such as the time allocated for an individual patient, are a separate issue. They probably require solutions at the level of government laws and ordinances. It is necessary to train GPs in the field of behavioural addictions and FOMO, including prevention, diagnosis, and short-term interventions. This type of training should be also addressed to school nurses, general practice nurses, educators as well as tutors.

Cooperation between GPs and the staff of psychological and pedagogical counselling centres should also be strengthened. Such cooperation could help shape a young adult who will consciously undertake healthy activities ${ }^{(39)}$. An educational campaign known as "Get over with FOMO. Log out to the real world" was launched in $2016^{(44)}$. Subject literature increasingly draws attention to the "joy of missing out" (JOMO) $)^{(45)}$.

Information brochures, leaflets and posters about FOMO should be developed for distribution in general medicine practices. Guides for parents and guardians to provide assistance on how to cope with a child addicted to the Internet, developed in cooperation with psychologists and educators, would be also helpful ${ }^{(2)}$. 
Perhaps it would be worth considering pilot programmes for a cooperation between GPs and clinical psychologists in general medicine practices in Poland. In 2002, an educational project for psychologists to prepare them for cooperation with doctors was launched at the University of Virginia School of Medicine. It was based on the assumption that the collaboration between psychologists and doctors is an essential condition for integrated healthcare. Psychologists learned about the principles of functioning of primary health care centres, while GPs practised interpersonal and communication skills. A similar project was implemented again in 2007. Psychologists acquired the skills for implementing behavioural interventions needed for the short-term contacts with patients, which was intended to ensure integrated basic healthcare for the society. Additionally, they were educated, among other things, on how to assess cognitive processes and behaviour in a general practice setting ${ }^{(46)}$. In randomly selected primary care centres in Rome, psychologists collaborated with GPs for 3 years. The cooperation involved, among other things, joint conversations with patients. The majority of patients approved of the initiative. During the experiment, only 4 patients asked for consultation only with a doctor, without the presence of a psychologist. The presence of a psychologist itself contributed to a more detailed description of symptoms (including the ones experienced for a long time) provided by patients, which allowed for a more detailed questions on the part of the doctor, and thus a more accurate diagnosis. The advantages of cooperation between a GP and a psychologist include, among other things, access to psychologists for the general society, reduction of social stigma due to the need for psychological consultation, intervention of a psychologist in the initial stage of threat ${ }^{(47)}$. Similar pilot programmes, especially those targeting adolescents, could be implemented in Poland. These could relate to cooperation between GPs and clinical psychologists in the prevention and early detection of risky behaviours among adolescents.

Implementation of a pilot programme for the prevention of cyber diseases, financed by the National Heath Fund, could be a solution. The programme would target 15-18-year-olds. It would consist of a basic stage (implemented by primary care physicians) and a specialist stage. The possibility of establishing highly specialised behavioural addiction outpatient clinics financed by the National Health Fund should be considered for both adolescents and young adults.

At the same time, we should not forget about the opportunities associated with being online. Social media create the most comprehensive, generally accessible educational and professional environment. Rational use of these media allows for expanding career opportunities. Furthermore, they enable building a network of contacts, which inspires joint actions and ideas as well as helps share knowledge ${ }^{(48)}$. Generally, the idea is to teach a young person how to use this hypermedium.

\section{Conflict of interest}

The authors do not report any financial or personal connections with other persons or organisations, which might negatively affect the contents of this publication and/or claim authorship rights to this publication

\section{References}

1. Jabłońska MR: Człowiek w cyberprzestrzeni. Wprowadzenie do psychologii Internetu. Wydawnictwo Uniwersytetu Łódzkiego, Łódź 2018.

2. Klimczak MK: Uzależnienie młodzieży od internetu jako problem wychowawczy i moralny. Wydawnictwo SQL, Olsztyn 2012.

3. Kotyśko M, Izdebski P, Michalak M et al.: Nadmierne korzystanie z sieci społecznościowych. Alkohol Narkom 2014; 27: 177-194.

4. Warzecha K: Portale społecznościowe formą rozrywki i komunikacji współczesnej młodzieży - analiza statystyczna. Studia Ekonomiczne. Zeszyty Naukowe Uniwersytetu Ekonomicznego w Katowicach 2017; 318: 84-107.

5. Makaruk K, Wójcik S (eds.): EU NET ADB - Badanie nadużywania internetu przez młodzież w Polsce i Europie. Fundacja Dzieci Niczyje, Warszawa 2012.

6. Klingemann JI, Sierosławski J: Korzystanie z mediów społecznościowych wśród młodzieży. Wyniki badań ESPAD w Polsce na tle wybranych krajów europejskich. Alcohol Drug Addict 2018; 31: 87-106.

7. Motow I: Fonoholizm jako nowe uzależnienie wśród nastolatków. In: Bębas S, Plis J, Bednarek J (eds.): Patologie w cyberświecie. $1^{\text {st }}$ ed., Wyższa Szkoła Handlowa w Radomiu, Radom 2012: 461-484.

8. Kirwil L: Polskie dzieci w Internecie. Zagrożenia i bezpieczeństwo część 2 . Częściowy raport z badań EU KIDS Online przeprowadzonych wśród dzieci w wieku 9-16 lat i ich rodziców. SWPS - EU Kids Online - PL, Warszawa 2011.

9. Dębski M: Fonoholizm - problemowe korzystanie ze smartfonów jako negatywny przejaw funkcjonowania w społeczeństwie cyfrowym. Uzależnienia 2017; 2/78: 38-45.

10. Conlin L, Billings AC, Averset L: Time-shifting vs. appointment viewing: the role of fear of missing out within TV consumption behaviors. Communication \& Society 2016; 29 (4): 151-164.

11. Jupowicz-Ginalska A, Jasiewicz J, Kisilowska M et al.: FOMO. Polacy a lęk przed odłączeniem - raport $\mathrm{z}$ badań. Warszawa 2018.

12. Czopek J: Dlaczego tak łatwo oddajemy mediom elektronicznym nasz czas? Kilka uwag o nieetycznej technologii. Edukacja - Technika - Informatyka 2018; 9: 201-205.

13. Spitzer M: CYBERKRANK! Wie das digitalisierte Leben unsere Gesundheit ruiniert. Droemer Verlag, München 2015.

14. Andreassen CS, Pallesen S: Social network site addiction - an overview. Curr Pharm Des 2014; 20: 4053-4061.

15. Buglass SL, Binder JF, Betts LR et al.: Motivators of online vulnerability: the impact of social network site use and FOMO. Comput Human Behav 2017; 66: 248-255.

16. Naren V, Sobana J, Jaiganesh K: Prevalence of Internet addiction and its impact on the physiological balance of mental health. Natl J Physiol Pharm Pharmacol 2016; 6: 97-100.

17. Tomczyk $€$, Selmanagic-Lizde E: Fear of Missing Out (FOMO) among youth in Bosnia and Herzegovina - scale and selected mechanisms. Child Youth Serv Rev 2018; 88: 541-549.

18. Australian Psychological Society: Stress \& wellbeing. How Australians are copying with life. The findings of the Australian Psychological Society Stress and Wellbeing in Australia survey, Australia 2015.

19. Barry CT, Sidoti CL, Briggs SM et al.: Adolescent social media use and mental health from adolescent and parent perspectives. J Adolesc 2017; 61: 1-11.

20. Błachnio A, Przepiorka A: Dysfunction of self-regulation and selfcontrol in Facebook addiction. Psychiatr Q 2016; 87: 493-500.

21. Riordan BC, Flett JAM, Hunter JA et al.: Fear of missing out (FoMO): the relationship between FoMO, alcohol use, and alcohol-related consequences in college students. J Psychiatry Brain Funct 2015; 2: 9. 
22. Poprawa R: Test problematycznego używania Internetu. Adaptacja i ocena psychometryczna Internet Addiction Test K. Young. Przegląd Psychologiczny 2011; 54: 193-216.

23. Wolniewicz CA, Tiamiyu MF, Weeks JW et al.: Problematic smartphone use and relations with negative affect, fear of missing out, and fear of negative and positive evaluation. Psychiatry Res 2018; 262: 618-623.

24. Eide TA, Aarestad SH, Andreassen CS et al.: Smartphone restriction and its effect on subjective withdrawal related scores. Front Psychol 2018; 9: 1444.

25. Oberst U, Wegmann E, Stodt B et al.: Negative consequences from heavy social networking in adolescents: the mediating role of fear of missing out. J Adolesc 2017; 55: 51-60.

26. Franchina V, Vanden Abeele M, van Rooij AJ et al.: Fear of missing out as a predictor of problematic social media use and phubbing behavior among Flemish adolescents. Int J Environ Res Public Health 2018; 15. pii: E2319.

27. Alt D, Boniel-Nissim M: Links between adolescents' deep and surface learning approaches, problematic internet use, and fear of missing out (FoMO). Internet Interv 2018; 13: 30-39.

28. Jenaro C, Flores N, Gómez-Vela M et al.: Problematic internet and cell-phone use: psychological, behavioral, and health correlates. Addict Res Theory 2007; 15: 309-320.

29. Sahin S, Ozdemir K, Unsal A et al.: Evaluation of mobile phone addiction level and sleep quality in university students. Pak J Med Sci 2013; 29: 913-918.

30. Dhir A, Yossatorn $Y$, Kaur $P$ et al.: Online social media fatigue and psychological wellbeing - a study of compulsive use, fear of missing out, fatigue, anxiety and depression. Int J Inf Manage 2018; 40: 141-152.

31. Pantic I, Damjanovic A, Todorovic J et al.: Association between online social networking and depression in high school students: behavioral physiology viewpoint. Psychiatr Danub 2012; 24: 90-93.

32. Makaruk K: Korzystanie $z$ portali społecznościowych przez młodzież. Wyniki badania EU NET ADB. Dziecko Krzywdzone. Teoria, Badania, Praktyka 2013; 12: 69-79.

33. Demirci K, Akgönül M, Akpinar A: Relationship of smartphone use severity with sleep quality, depression, and anxiety in university students. J Behav Addict 2015; 4: 85-92.

34. Leena K, Tomi L, Arja RR: Intensity of mobile phone use and health compromising behaviours - how is information and communication technology connected to health-related lifestyle in adolescence? J Adolesc 2005; 28: 35-47.

35. Bortkiewicz A: Skutki zdrowotne działania pól elektromagnetycznych - przegląd badań. Podstawy i Metody Oceny Środowiska Pracy 2008; 4/58: 67-87.
36. Croft RJ, Chandler JS, Burgess AP et al.: Acute mobile phone operation affects neural function in humans. Clin Neurophysiol 2002; 113: 1623-1632.

37. Hardell L, Carlberg M, Söderqvist F et al.: Long-term use of cellular phones and brain tumours: increased risk associated with use for $\geq 10$ years. Occup Environ Med 2007; 64: 626-632.

38. Takao M, Takahashi S, Kitamura M: Addictive personality and problematic mobile phone use. Cyberpsychol Behav 2009; 12: 501-507.

39. Wróblewska I, Steciwko A: Promocja zdrowia jako ważny element pracy lekarza i pieleggniarki w podstawowej opiece zdrowotnej. In: Steciwko A, Barański J (eds.): Relacja lekarz-pacjent. Zrozumienie i współpraca. $1^{\text {st }}$ ed., Elsevier Urban \& Partner, Wrocław 2013: 140-152.

40. Charzyńska E, Góźdź J: W sieci uzależnienia. Polska adaptacja Skali Uzależnienia od Facebooka (the Bergen Facebook Addiction Scale) C.S. Andreassen, T. Torsheima, G.S. Brunborga i S. Pallesena. Chowanna 2014; 1/42: 163-185.

41. Barański J, Steciwko A: Wzajemne zrozumienie oraz współpraca lekarza i pacjenta - panorama problemów. In: Steciwko A, Barański J (eds.): Relacja lekarz-pacjent. Zrozumienie i współpraca. $1^{\text {st }} \mathrm{ed}$., Elsevier Urban \& Partner, Wrocław 2013: 3-12.

42. Miller WR, Rollnick S: Motivational Interviewing: Preparing People for Change. $2^{\text {nd }}$ ed., Guilford Press, New York 2002.

43. Woynarowska B: Edukacja zdrowotna dzieci, młodzieży i rodziców. In: Woynarowska B (ed.): Profilaktyka w pediatrii. $2^{\text {nd }}$ ed., Wydawnictwo Lekarskie PZWL, Warszawa 2008: 94-102.

44. „Odpuść FOMO”, czyli do czego prowadzi ciągła potrzeba „bycia na bieżąco". Available from: http://www.proto.pl/aktualnosci/odpuscfomo-czyli-do-czego-prowadzi-ciagla-potrzeba-bycia-na-biezaco.

45. Stamp PA: Classroom management and social media: FOMO vs. JOMO. BAASANA International Conference Proceedings, August 17-19 2016: 157-158.

46. Bluestein D, Cubic BA: Psychologists and primary care physicians: a training model for creating collaborative relationships. J Clin Psychol Med Settings 2009; 16: 101-112.

47. Solano L, Pirrotta E, Ingravalle V et al.: The family physician and the psychologist in the office together: a response to fragmentation. Ment Health Fam Med 2009; 6: 91-98.

48. Różański A: Media społecznościowe: współczesne środowisko edukacyjne czy „cyfrowe tsunami”? Ann UMCS Sect J 2017; 30: 205-216. 